\title{
Statins in acute neurologic disease: which one, which dose, when to start, and when not to stop
}

\author{
Bong-Su Kang ${ }^{1}$, Gene Sung ${ }^{2,3}$, May Kim-Tenser ${ }^{2,3}$, Nerses Sanossian ${ }^{2,3}$ \\ ${ }^{1}$ Department of Neurology, Korea University Anam Hospital, Seoul 136-705, South Korea. \\ ${ }^{2}$ Department of Neurology, University of Southern California, Los Angeles, CA 90026, USA. \\ ${ }^{3}$ Department of Roxanna Todd Hodges Comprehensive Stroke Clinic, University of Southern California, Los Angeles, CA 90026, \\ USA.
}

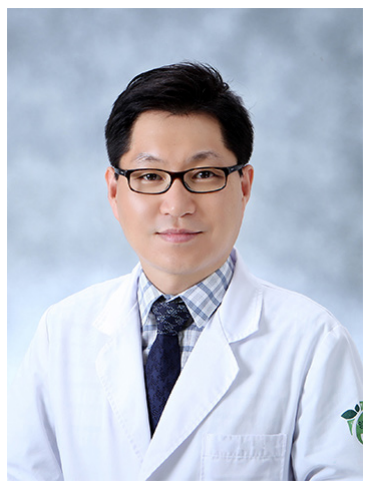

Dr. Bong-Su Kang finished neurology residency and fellowship of adult epilepsy at Seoul National University Hospital in South Korea, followed by visiting fellowship in neurocritical care at University of Southern California in USA. Dr. Kang is currently clinical assistance professor in Korea University Anam Hospital since 2014.

\section{A B S T R A C T}

Statins could have physiologic properties that may benefit patients that have been diagnosed with various acute neurological diseases. This review aims tosummarize the literature pertaining to stain use in acute neurological disease such as subarachnoid hemorrhage, intracerebral hemorrhage $(\mathrm{ICH})$, cerebral ischemia $(\mathrm{Cl})$, traumatic brain injury, status epilepticus and meningitis. The authors reviewed published abstracts and manuscripts pertaining to experimental and clinical trials relevant to statins in acute neurological disease. Although acute statin therapy in the setting of subarachnoid hemorrhage might reduce delayed cerebral ischemia and mortality, it should not be considered standard care at this time. Acute statins therapy has not demonstrated anybenefit yet following an $\mathrm{ICH}$ or $\mathrm{Cl}$. Acute statin withdrawal may worsen outcome in acute $\mathrm{Cl}$. Observational and case-control studies suggest that pretreatment with statin at time of onset may be associated with better outcomes. Even though preclinical studies have shown statins to have beneficial effects, there has been no clinical evidence. In conclusion, current published studies have not shown that acute statin therapy has any benefical effects in acute neurologic diseases and therefore further large randomized clinical trials are needed.

Key words: Statin; dyslipidemia; stroke prevention; subarachnoid hemorrhage; intracerebral hemorrhage; cerebral infarction

\section{INTRODUCTION}

The drug class of potent inhibitors of cholesterol biosynthesis called the 3-hydroxy-methyglutaryl

Corresponding Author: Dr. Gene Sung, Department of Neurology, LAC+USC Medical Center, 1100 North State Street, Los Angeles, CA 90026, USA. Email: gsung@usc.edu

\begin{tabular}{|l|l|}
\hline \multicolumn{2}{|c|}{ Access this article online } \\
\hline Quick Response Code: & Website: \\
\hline & http://www.nnjournal.net \\
\cline { 2 - 2 } & DOl: 10.20517/2347-8659.2015.27 \\
&
\end{tabular}

coenzyme A reductase inhibitors, are also commonly referred to as statins. ${ }^{[1]}$ They are classified as a therapeutic class of lipid lowering agents and are established in the primary and secondary prevention of vascular diseases. Recent experimental and clinical evidence suggests that statins have cholesterol

This is an open access article distributed under the terms of the Creative Commons Attribution-NonCommercial-ShareAlike 3.0 License, which allows others to remix, tweak, and build upon the worknon-commercially, as long as the author is credited and the new creations are licensed under the identical terms.

For reprints contact: service@oaepublish.com

Cite this article as: Kang BS, Sung G, Kim-Tenser M, Sanossian N Statins in acute neurologic disease: which one, which dose, when to start, and when not to stop. Neuroimmunol Neuroinflammation 2016;3:133-40.

Received: 16-06-2015; Accepted: 25-12-2015. 


\begin{tabular}{|c|c|c|c|c|c|c|c|c|}
\hline Study & Size (S:P) & $\begin{array}{l}\text { Statin } \\
\text { therapy }\end{array}$ & Initiation & Duration & Vasospasm & DCI & Poor outcome & Mortality \\
\hline \multicolumn{9}{|c|}{ Randomized controlled trials } \\
\hline Tseng et al. ${ }^{[15]}$ & $80(40: 40)$ & Pra $40 \mathrm{mg} \mathrm{qd}$ & $72 \mathrm{~h}$ & $\begin{array}{l}14 \text { days or } \\
\text { discharged }\end{array}$ & $\begin{array}{c}43 \% \text { vs. } 63 \% \\
(P=0.006)\end{array}$ & $\begin{array}{l}5 \% \text { vs. } 30 \% \\
(P<0.001)\end{array}$ & $\begin{array}{l}43 \% \text { vs. } 53 \% \\
(P=0.7)\end{array}$ & $\begin{array}{c}5 \% \text { vs. } 20 \% \\
(P=0.04)\end{array}$ \\
\hline Lynch et al. ${ }^{[16]}$ & $39(19: 20)$ & $\begin{array}{l}\text { Sim } 80 \mathrm{mg} \\
\text { qd }\end{array}$ & $48 \mathrm{~h}$ & 14 days & $\begin{array}{c}26 \% \text { vs. } 60 \% \\
(P=0.03)\end{array}$ & $\begin{array}{c}26 \% \text { vs. } 60 \% \\
(P=0.03)\end{array}$ & N/A & $\mathrm{N} / \mathrm{A}$ \\
\hline Chou et al..$^{[17]}$ & $29(19: 20)$ & $\begin{array}{l}\text { Sim } 80 \mathrm{mg} \\
\text { qd }\end{array}$ & $96 \mathrm{~h}$ & $\begin{array}{l}21 \text { days } \\
\text { or ICU } \\
\text { discharged }\end{array}$ & $\begin{array}{l}68 \% \text { vs. } 50 \% \\
(P=0.24)\end{array}$ & $\begin{array}{c}37 \% \text { vs. } 50 \% \\
(P=0.41)\end{array}$ & $\begin{array}{c}63 \% \text { vs. } 50 \% \\
(P=0.41)\end{array}$ & $\begin{array}{l}0 \% \text { vs. } 15 \% \\
(P=0.23)\end{array}$ \\
\hline \multicolumn{9}{|c|}{ Observational cohort study } \\
\hline Kramer et al. ${ }^{[21]}$ & $150(71: 79)$ & $\begin{array}{l}\text { Sim } 80 \mathrm{mg} \\
\text { qd }(93 \%)\end{array}$ & $\begin{array}{l}\text { Previously } \\
\text { used }\end{array}$ & 14 days & $\begin{array}{c}42 \% \text { vs. } 41 \% \\
(P=0.91)\end{array}$ & $\begin{array}{c}28 \% \text { vs. } 23 \% \\
(P=0.46)\end{array}$ & $\begin{array}{l}28 \% \text { in both } \\
\text { group }\end{array}$ & N/A \\
\hline McGirt et al.[22] & $340(170: 170)$ & 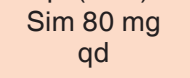 & $\mathrm{N} / \mathrm{A}$ & 14 days & $\begin{array}{l}25.3 \% \text { vs. } 30.5 \% \\
\quad(P=0.277)\end{array}$ & $\mathrm{N} / \mathrm{A}$ & $\begin{array}{c}21.7 \% \text { vs. } 18.2 \% \\
(P=0.416)\end{array}$ & $\begin{array}{c}18 \% \text { vs. } 15 \% \\
(P=0.468)\end{array}$ \\
\hline Kern et al. ${ }^{[23]}$ & $135(72: 58)$ & Pra $40 \mathrm{mg} \mathrm{qd}$ & $\mathrm{N} / \mathrm{A}$ & 14 days & $\begin{array}{l}52 \% \text { vs. } 50 \% \\
(P=0.17)\end{array}$ & $\mathrm{N} / \mathrm{A}$ & \multicolumn{2}{|c|}{$\begin{array}{c}34.7 \% \text { vs. } 31.0 \% 20.8 \% \text { vs. } 13.7 \% \\
(P=0.95) \quad(P=0.4)\end{array}$} \\
\hline Kern et al. ${ }^{[23]}$ & $100(49: 51)$ & $\begin{array}{l}\operatorname{Sim} 20,40 \\
\mathrm{mg} \text { qd }\end{array}$ & $\mathrm{N} / \mathrm{A}$ & 14 days & N/A & $\begin{array}{c}20 \% \text { vs. } 16 \% \\
(P=0.74)\end{array}$ & N/A & $\begin{array}{c}14 \% \text { vs. } 27 \% \\
(P=0.20)\end{array}$ \\
\hline
\end{tabular}

S:P: statin:placebo; Pra: pravastatin; Sim: simvastatin; qd: once a day; TCD: transcranial Doppler; DCI: delayed cerebral ischemia; N/A: not available; ICU: intensive care unit; H: hours.
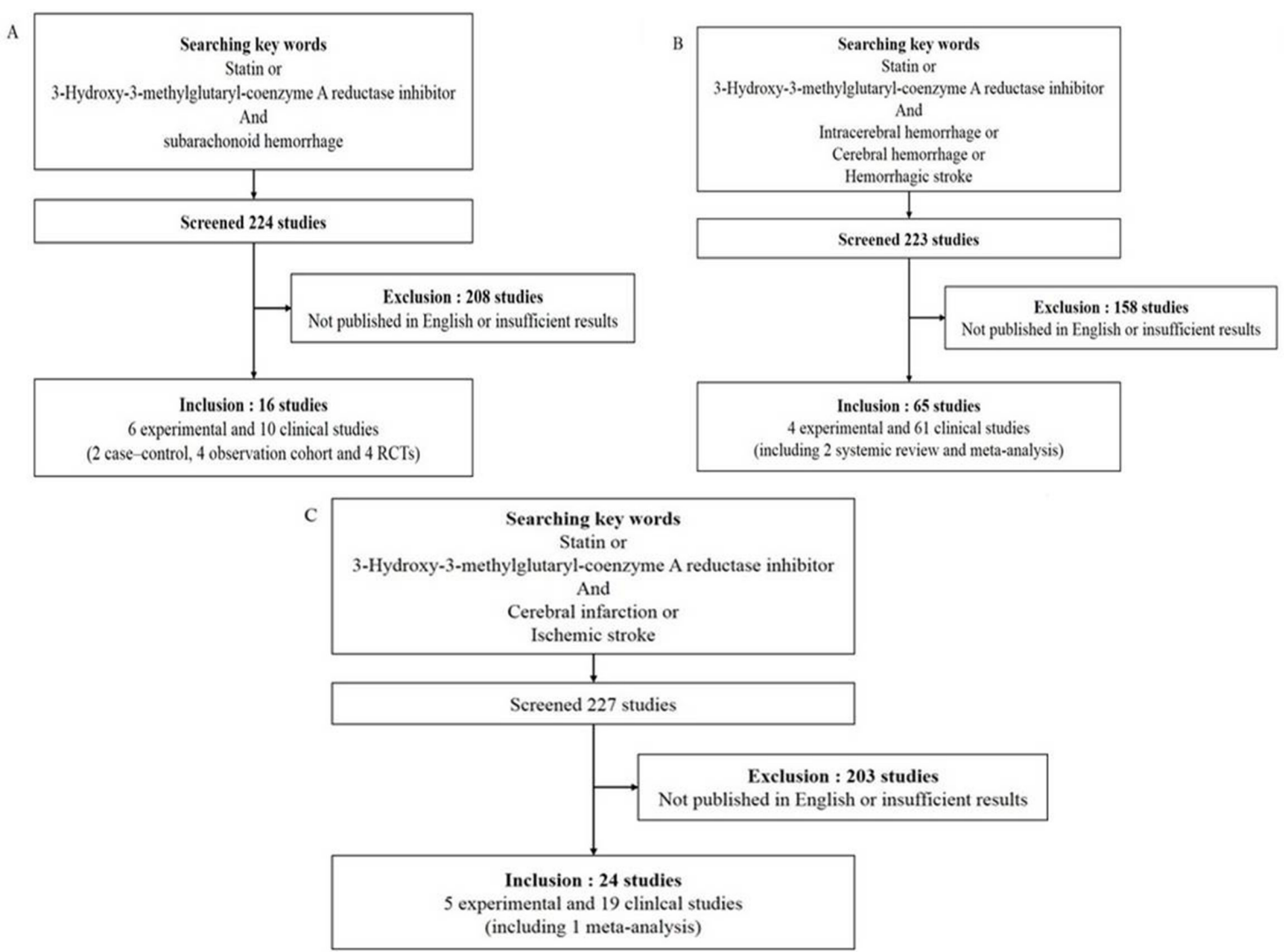

Figure 1: Flow chart of the literature selection for (a) subarachnoid hemorrhage, (b) intracerebral hemorrhage and (c) acute cerebral infarction. RCTs: randomized controlled trials

independent beneficial pleiotropic effects, including

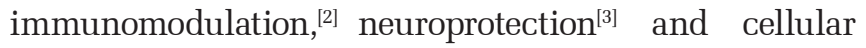
senescence. ${ }^{[4]}$ These properties could be beneficial in various acute neurologic diseases.

Statins were initially developed for secondary prevention of cardiovascular disease via secondary to dyslipidemia. Initial studies in neurological disease focused on patients with stroke or at high risk of stroke. Long-term statin therapy was associated with meaningful reductions in stroke, myocardial infarction and vascular death in both primary ${ }^{[5]}$ and secondary stroke prevention..$^{[6]}$ Promising data has been published from studies of acute myocardial infarction $^{[7]}$ and casecontrolled studies of statin use prior to stroke ${ }^{[8]}$ led to an interest in determining the role of statins in the acute setting, such asreducing early recurrence of ischemic event or beneficial for long-term functional outcome.

The aim of this review is to summarize the literature regarding the use of statins in common acute neurological diseases; subarachnoid hemorrhage (SAH), intracerebral 
Table 2: Summary of the published clinical studies for statin with intracranial hemorrhage

\begin{tabular}{|c|c|c|c|c|c|c|}
\hline \multirow[t]{2}{*}{ Study } & \multirow[t]{2}{*}{ Study type } & \multirow[t]{2}{*}{ Size (s:n) } & \multirow[t]{2}{*}{ Statin therapy } & \multicolumn{3}{|c|}{ Outcome } \\
\hline & & & & Timing & $\begin{array}{l}\text { Good outcome } \\
\text { (OR, } 95 \% \mathrm{CI})\end{array}$ & Mortality (OR, 95\% CI) \\
\hline Leker et al. ${ }^{[33]}$ & Observation & $312(89: 223)$ & Any & At discharge & $\begin{array}{c}2.97,1.25-7.35 \\
(P=0.015)\end{array}$ & $\begin{array}{c}0.25,0.09-0.63 \\
(P=0.004)\end{array}$ \\
\hline Biffi et al. ${ }^{[28]}$ & Observation & 699 (238: 461) & Any & 90 days & $\begin{array}{c}2.08,1.37-3.17 \\
(P=0.004)\end{array}$ & $\begin{array}{c}0.47,0.32-0.70 \\
\quad(P=0.005)\end{array}$ \\
\hline Biffi et al. ${ }^{[28]}$ & $\begin{array}{c}\text { Meta-analysis } \\
\text { ( } 6 \text { obs + 1 RCT) }\end{array}$ & 2521 (698: 1,823) & Any & 90 days & $\begin{array}{c}1.91,1.38-2.65 \\
(P<0.0001)\end{array}$ & $\begin{array}{c}0.55,0.42-0.72 \\
(P<0.0001)\end{array}$ \\
\hline
\end{tabular}

Observed outcome with pretreatment of statin. s:n: statin: no statin; obs: observation; RCT: randomized controlled trial; ICH: intracerebral hemorrhage

\begin{tabular}{|c|c|c|c|c|c|}
\hline Study & Study type & Population & Size & Statin therapy & Risk of ICH \\
\hline Goldstein et al. ${ }^{[34]}$ & RCTs & $\begin{array}{l}\text { Treatment after stroke } \\
\text { (include TIA) }\end{array}$ & 88 (s55: n33) & Atorvastatin $80 \mathrm{mg}$ & $\begin{array}{c}\text { OR } 1.68(95 \% \mathrm{Cl} 1.09-2.59, \\
P=0.02)\end{array}$ \\
\hline \multirow[t]{2}{*}{ Hackam et al. ${ }^{[35]}$} & $\begin{array}{l}\text { Meta-analysis } \\
23 \text { RCTs }\end{array}$ & $\begin{array}{l}\text { Statin with various cause } \\
526,518 \text { patients-years } \\
\text { (median } 3.9 \text { years), } 497 \\
\text { ICH }\end{array}$ & & Any & RR $1.10(95 \%$ Cl 0.86-4.14) \\
\hline & 19 Obs & $\begin{array}{l}219,459 \text { patients-years } \\
\text { (median } 3.0 \text { years), } 14280 \\
\text { ICH }\end{array}$ & & & $\begin{array}{l}\text { RR } 0.94 \text { (95\% Cl 0.81-1.10) } \\
\text { for } 12 \text { observational cohort } \\
\text { RR } 0.60 \text { ( } 95 \% \mathrm{Cl} 0.41-0.88) \\
\text { for } 6 \text { case control study }\end{array}$ \\
\hline
\end{tabular}

RCTs: randomized controlled trials; TIA: transient ischemia attach; OR: odds ratio; CI: cerebral ischemia; ICH: intracerebral hemorrhage; RR: relative risk; Obs: observation

hemorrhage (ICH), cerebral infarction, traumatic brain injury (TBI), status epilepticus and meningitis. Studies were identified by performing a PubMed search using following key words: "statin" and each disease which was discussed in this review. Study selection was performed by two reviewers independently and the third reviewer would step in if there were any disagreement. The studies only published in English were selected. Discussion between reviewers was made to get a final consensus. The results were described in Figure 1. The main focus was the evidence for timing of statin initiation as well as specific agent and doses in the patient presenting to the emergency department and acute care unit.

\section{SAH}

Symptomatic cerebral vasospasm and delayed cerebral ischemia (DCI) is a major source of disability, unfavorable outcome and cause of death after aneurysmal SAH. Although the exact mechanism of SAH associated vasospasm and DCI are not well known, experimental studies suggest multifactorial pathogenesis involving inflammation, No depletion, endothelial injury, free radical and microvascular by autoregulation..$^{[9-11]}$ The pleiotropic effects of statin may be beneficial in attenuation of SAH associated vasospasm and DCI via inhibit the underlying mechanism of vasospasm and DCI. The results from 3 different animal models (mice, rabbits and dogs), have supported this hypothesis. ${ }^{[12-14]}$

Clinical evidence suggesting benefits in by reducing DCI and possibly vasospasm and early in-hospital mortality that has come from 6 randomized controlled trials (RCTs) ${ }^{[15-20]}$ (two of which have only published as abstracts ${ }^{[19,20]}$, four observational cohort studies ${ }^{[21-24]}$ [Table 1] and two case-control studies. ${ }^{[25,26]}$

All 6 RCT were phase II, single-center trials and none of which enrolled more than 100 patients. ${ }^{[15-20]}$ One RCT $^{[17]}$ focused on patents with Fisher grade 3 and the other RCTs ${ }^{[15,16,18-20]}$ included all grades. The statins used in these trials were either pravastain $40 \mathrm{mg}^{[15,19]}$ or simvastatin $80 \mathrm{mg}^{[16-18,20]}$ administrated within 96 h (range from 24-96 h) following aneurysmal SAH. Three RCTs administered statin for 2 weeks, ${ }^{[15,16,18]}$ two used statin for 3 weeks, ${ }^{[17,20]}$ and the other prescribed statins when patients were admitted to the intensive care unit. ${ }^{[19]}$ Because the definition of vasospasm varied between trials, the effects of statins on vasospasm were inconsistent. Vasospasm-related DCIs was based on both neurological deterioration and neuroimaging findings in all trials. Statin therapy reduced the incidence of DCI in three trials, ${ }^{[15,16,18]}$ but showed a non-significant trend to reduce the DCI in two trials ${ }^{[17,20]}$ and was neutral in one trial. ${ }^{[18]}$ None of these trials showed significant benefits of early statin therapy on functional outcomes by modified Rankin Scale or Glasgow Outcome Score. ${ }^{[15,17-20]}$ Mortality was reduced by statin therapy in three RCTs, ${ }^{[15,17,20]}$ but not in others. ${ }^{[18,19]}$

A meta-analysis with high quality four RCTs ${ }^{[15-18]}$ showed that use of statin after SAH significantly reduced both DCI [odd ratios (OR) 0.41, 95\% confidence interval (CI) $0.20-0.82, P<0.001$ ) and mortality (OR 0.29, 95\% CI $0.09-0.93, P=0.04)^{[27]}$ When data from non-published 


\begin{tabular}{|c|c|c|c|c|}
\hline \multirow[t]{2}{*}{ Study } & \multirow[t]{2}{*}{ Study type } & \multirow[t]{2}{*}{ Size (s:n) } & \multicolumn{2}{|l|}{ Outcome } \\
\hline & & & Result & Definition \\
\hline Marti-Favregas et al..$^{[8]}$ & Observation & $167(30: 137)$ & $\begin{array}{c}\text { OR } 5.55 \\
(95 \% \mathrm{Cl} 1.42-0.80, P=0.012)\end{array}$ & $\begin{array}{l}\text { Good outcome at } 3 \\
\text { months }\end{array}$ \\
\hline Elkind et al. ${ }^{[43]}$ & Observation & $650(57: 593)$ & $1.8 \%$ vs. $10.6 \%(P=0.04)$ & Mortality at 3 months \\
\hline Greisenegger et al. ${ }^{[44]}$ & Observation & 1,691 (152:1,539) & $\begin{array}{c}6 \% \text { vs. } 14 \%, \text { OR } 0.37 \\
(95 \% \mathrm{Cl} 0.19-0.74, P=0.004)\end{array}$ & Severe stroke (mRS 5-6) \\
\hline Flint et al..$^{[45]}$ & $\begin{array}{c}\text { Observation } \\
\text { Treatment pre- or during } \\
\text { hospitalization }\end{array}$ & $12,689(6,294: 6,395)$ & $\begin{array}{c}22.1 \% \text { vs. } 33.8 \%, \text { HR } 0.59 \\
(95 \% \mathrm{Cl} 0.53-0.65, P<0.001)\end{array}$ & Mortality at 1 year \\
\hline
\end{tabular}

Pretreatment of statin and associated outcome. s:n: statin: no statin; OR: odds ratio; Cl: cerebral ischemia; HR: heart rate

\begin{tabular}{|c|c|c|c|c|}
\hline \multirow[t]{2}{*}{ Study } & \multirow[t]{2}{*}{ Study type } & \multirow[t]{2}{*}{ Size } & \multicolumn{2}{|c|}{ Outcome } \\
\hline & & & Result & Definition \\
\hline Flint et al. ${ }^{[45]}$ & Observation & 468 of 3,749 & $\begin{array}{c}46.2 \% \text { vs. } 22.1 \%, \text { HR } 2.5 \\
(95 \% \mathrm{Cl} 2.1-2.9, P<0.001)\end{array}$ & Mortality at 1 year \\
\hline \multirow[t]{2}{*}{ Blanco et al. ${ }^{[46]}$} & Randomized controlled & 46 of 89 & $\begin{array}{c}65.2 \% \text { vs. } 20.9 \%, \text { OR } 8.67 \\
\text { (95\% Cl 3.05-24.63, } P<0.0001)\end{array}$ & Early neurologic deterioration \\
\hline & & & $\begin{array}{c}60.0 \% \text { vs. } 39.0 \%, \text { OR } 4.66 \\
(95 \% \mathrm{Cl} 1.46-14.91, P=0.043)\end{array}$ & Death or dependency \\
\hline
\end{tabular}

OR: odds ratio; $\mathrm{Cl}$ : cerebral ischemia; HR: Heart rate

\begin{tabular}{|c|c|c|c|c|}
\hline \multirow[t]{2}{*}{ Study } & \multirow[t]{2}{*}{ Study type } & \multirow[t]{2}{*}{ Size (s:n) } & \multicolumn{2}{|c|}{ Outcome } \\
\hline & & & Result & Definition \\
\hline Flint et al. ${ }^{[45]}$ & Observation & $8,940(2,545: 6,395)$ & $\begin{array}{c}19.4 \% \text { vs. } 33.8 \%, \text { HR0.55 } \\
(95 \% \mathrm{Cl} 0.50-0.61, P<0.001)\end{array}$ & Mortality at 1 year \\
\hline Kennedy et al..$^{[47]}$ & Randomized controlled & 199:193 & $\begin{array}{c}10.6 \% \text { vs. } 7.3 \%, \text { RR } 1.3 \\
(95 \% \mathrm{Cl} 0.7-2.4, P=0.25)\end{array}$ & Stroke within 90 days \\
\hline Squizzato et al. ${ }^{[48]}$ & Meta-analysis of 7 RCTs & Total 431 & OR 1.51 (95\% Cl 0.60-3.81) & Mortality \\
\hline
\end{tabular}

s:n: statin: no statin; OR: odds ratio; Cl: cerebral ischemia; HR: heart rate; RR: relative risk; RCTs: randomized controlled trials

$\operatorname{RCTs}^{[19,20]}$ was included in the analysis, statin therapy significantly reduced DCI (fixed model, OR 0.38, 95\% CI 0.23-0.65, $P<0.001$ ) and was associated with a trend toward reduced mortality (fixed model, OR 0.51, 95\% CI $0.25-1.02, P=0.06) .^{[27]}$

Four single centers reported observation from cohorts that ranged from 49 to 170 patients of statin therapy following aneurysmal SAH. ${ }^{[21-24]}$ These observational studies were considered to low quality because of relatively small sample sizes, heterogeneity in baseline, clinical management and definition of clinical outcome. A meta-analysis was performed using these 4-observation cohort studies, one case control study ${ }^{[25]}$ and 6 RCTs which included 1,542 patients, whom 385 received statin. ${ }^{[27]}$ Statin use after aneurysmal SAH was not significant associated with reduced DCI (OR 0.96, 95\% CI $0.71-1.31, P=0.80$ ) or mortality (OR 1.16, 95\% CI 0.78-1.73, $P=0.47$ ). A more recent case-control study with atorvastatin suggested that the atorvastatin may have an anti-ischemic effect on imaging, but no clinical benefit after aneurysmal SAH. ${ }^{[26]}$

Consistent across all studied, there were no significant adverse effects associated with statin use after aneurysmal SAH. Asymptomatic elevation of liver enzyme within unexpected range was reported in 3 $\operatorname{RCTs}^{[15,17,18]}$ with only 1 patient having to discontinue statin because of myalgia. ${ }^{[18]}$

\section{ICH}

Although case-control studies of statin use before ICH has demonstrated an association with favorable outcomes and reduced mortality after $\mathrm{ICH},{ }^{[28]}$ there are no clinical studies of early initiation after ICH onset. Preclinical studies have shown beneficial effects on functional outcome in several animal models of ICH. ${ }^{[29-31]}$ Pleiotropic effects of statin such as neuroprotection and stimulation of neurogenesis and synaptogenesis might be contributed to this benefit. ${ }^{[32]} \mathrm{A}$ multicenter observational cohort study in Israel, including 89 patients with statin from a total of 312 ICH patients, showed that the prior use of statins was associated with good neurologic outcome at discharge of the patients (OR 2.97, 95\% CI 1.25-7.35, $P=0.015$ ) and reduced mortality or discharge to a nursing facility (OR $0.25,95 \%$ CI 0.09-0.63, $P=0.004$ ) [Tables 2 and 3]. ${ }^{[33]}$ Another single center study compared 90-day functional outcome in 238 pre-ICH statin cases and 461 statin-free cases. ${ }^{[28]}$ In this study, statin therapy was associated with improved functional outcome (OR 2.08, 95\% CI 1.37-3.17, $P=0.004)$ and reduced mortality (OR 0.47, $95 \%$ CI 0.32-0.70, $P=0.005$ ) without an effect on hematoma expansion. A meta-analysis was performed of 6 trials that usedstatins before ICH and the data showed a increased associationwith favorable outcomes (OR 1.19, 95\% CI 1.382.65, $P<0.0001)$ and reduced mortality (OR 0.55, 95\% CI 
$0.42-0.72, P<0.0001) .^{[28]}$

Although there have been concerned of statins increasing the risk of $\mathrm{ICH},{ }^{[34]}$ recent evidence suggest that the statins did not increase the risk of ICH. The Stroke Prevention by Aggressive Reduction of Cholesterol Levels (SPARCL) study found increased risk of subsequent ICH (unadjusted hazard ratio 1.68, 95\% CI 1.09-2.59) among subjects with prior stroke randomized to high-dose atorvastatin. ${ }^{[34]}$ Mild antithrombotic properties and lipid lowering effect of statins might be explained mechanism of association between statins and risk of ICH. However, recent meta-analysis have been reported that low cholesterol concentrations with intensive statin therapy did not correlated with risk for ICH. ${ }^{[36]}$ A recent large systematic review and meta-analysis of 23 randomized trials that provided a cumulative total of 526,518 patients years of follow-up with median 3.9 years found no evidence that statins were associated with developing ICH (risk ratio 1.10, 95\% CI 0.86-4.14). ${ }^{[35]}$ A second meta-analysis using 12 cohort studies that provide a total of 219,458 patient-years of follow-up or 6 case-control studies also did not show any risk of ICH with statin (each risk ratio 0.94, 95\% CI 0.81-1.10 and risk ratio 0.60, 95\% CI 0.41-0.88).

\section{ACUTE CEREBRAL INFARCTION}

There are numerous published work that demonstrates the beneficial effects of statins in animal models of ischemic stroke. These experimental models have evaluated effects of statin treatment prior to and after initiation of cerebral infarction. ${ }^{[37]}$ Statins have been shown to improve endothelial function and increase cerebral perfusion in the ischemic penumbra by improving no production immediately after treatment initiation. ${ }^{[38,39]}$ The anti-oxidative and anti-inflammatory properties of statins can affect secondary brain injury in the setting of ischemia. ${ }^{[40,41]} \mathrm{A}$ meta-analysis of 1,882 animals in 41 studies with ischemic occlusive stroke models showed that use of statin reduced infarction volume by $25 \%$ (95\% CI 21-30\%, $P<0.001$ ) and improved neurologic outcome by $20.36 \%$ (95\% CI 14-26\%, $P<0.001) .{ }^{[37]}$ Furthermore pretreatment with statin (median 14 days, range 5-14) was more effective than initiation after ischemia (median $4 \mathrm{~h}$, range 1-12) in infarct size reduction (33.57\%, 95\% CI 28.47-38.53\% vs. 16.02\%, 95\% CI 11.63-20.42\%; $\chi^{2}=408, P<0.001$ ) and improve neurologic outcome $(26.52 \%$, 95\% CI 15.05-37.99\% vs. 14.37\%, 95\% CI 7.26-21.48\%; $\left.\chi^{2}=17, P<0.001\right)$.

Most studies have shown that the use of statins at the time of ischemic stroke may confer a beneficial effect [Tables 4-6]. A population-based prospective study of 953 patients did not demonstrate early improvement in functional outcome after a first ischemic stroke event (OR 0.76, 95\% CI 0.53-1.09, $P=0.134) .{ }^{[42]}$ A small observational study noted more favorable outcomes in a 3-month period in which the patients were givenstatins for 3 months prior to the stroke statin group. ${ }^{[8]}$ Pretreatment with statin was associated with decreased in-hospital mortality ${ }^{[43]}$ and reduced stroke severity. ${ }^{[44]}$ The largest observational study evaluated 12,689 cases with acute ischemic stroke and found that statin use before and during hospitalization was strongly associated with improved survival (hazard ratio 0.59, 95\% CI 0.53-0.65, $P<0.001) \cdot{ }^{[45]}$

The question of in-hospital cessation of statin therapy is an important as stroke patients may be dysphagic and NPO after admission. This important question was addressed in the same large observational cohort of 12,689 cases and statin discontinuation in the acute phase of stroke, even for a brief period, was associated with a substantially greater risk of death (hazard ratio 2.5, 95\% CI 2.1-2.9; $P<0.001$ ). ${ }^{[45]}$ A small single-center randomized blinded study of statin withdrawal vs. continuation confirmed the need to continue treatment in this population. The acute statin withdrawal was associated with increase in early neurologic deterioration (OR 8.67, 3.05-24.63) and death/dependency (OR 4.66, 1.46-14.91). ${ }^{[46]}$

There is currently not enough evidence to confirm the beneficial effect of statin treatment in acute phase of ischemic stroke. A recent pilot clinical trial called "MISTICS" randomized 60 patients within 3 to $12 \mathrm{~h}$ after acute ischemic stroke to simvastatin or placebo for 90 days. This study showed that simvastatin therapy improved functional outcome $(46.4 \%$ vs. $17.9 \%, P=0.02){ }^{[49]}$ However, there were safety concerns as statin therapy was associated with increased incidence of infection (OR 2.4, 95\% CI 1.06-5.4) and a trend toincrease mortality (25.0\% vs. $10.7 \%, P=0.16$ ). Other randomized trials of statin therapy in acute stroke were limited by insufficient recruitment and insufficient data for analysis. ${ }^{[47,48,50]}$

One potential strategy for translating the efficacy of statins in preclinical models may be to use very high doses or intravenous routes for statin initiation. The neuroprotection with Statin Therapy for Acute Recovery Trial ${ }^{[51]}$ of 33 patients with acute ischemic stroke $<24 \mathrm{~h}$ of onset wastesting a short-term high-dose lovastatin at 1 , 3, 6, 8, and $10 \mathrm{mg} / \mathrm{kg}$ per day for 3 days. Patients were followed for 30 days andclinical and laboratory outcome measured in this Phase IB trial and the maximum tolerated dose was estimated to be $8 \mathrm{mg} / \mathrm{kg}$ per day.

Despite the lack of evidence for treating acute stroke with statin, there is no doubt that in-hospital initiation should occur when statin therapy is indicated. The SPARCL study clearly defined the role of statins in secondary stroke prevention, yet did not address the best 
time to initiate therapy. ${ }^{[52]}$ Studies comparing in-hospital initiation with outpatient initiation of preventative therapies have consistently shown better compliance over the long-term. ${ }^{[53]}$ For stroke patients, participation in a hospital-based prevention initiative with in-hospital initiation of antithrombotic, statin and antihypertensive was associated with very high rates of compliance at 3 months. ${ }^{[54]}$ In-hospital initiation of statins is associated with high rates of continuation and achievement of NationalCholesterolEducation Programguideline goals. ${ }^{[55]}$ In one study 92 statin-naïve patients with an indication for treatment, hospital initiation of statin therapy yielded a 93\% rate of adherence, lowered mean low-density lipoprotein cholesterol levels from 120 to $78 \mathrm{mg} / \mathrm{dL}$ and increased the proportion of patients with low-density lipoprotein cholesterol levels lower than $100 \mathrm{mg}$ from $36 \%$ to $88 \%$ at 3 months.

\section{TBI AND SCI}

Statins have demonstrated benefit in animal models of TBI and spinal cord injury (SCI). Statins treatment prior to experimental TBI was associated with reduced the cortical contusion volume ${ }^{[56]}$ and cerebral edema. ${ }^{[57,58]}$ Statin therapy after TBI in rat decreased post-traumatic apoptosis in hippocampus and peri-contusional cortex and increased neuronal proliferation leading to improvement of cognitive abilities. ${ }^{[59]}$ The experimental studies in preclinical SCI models also suggest that statin treatment could significantly improve functional outcome via anti-inflammatory and anti-apoptotic effects. ${ }^{[60,61]}$

Clinical evidence for the effect of statins moderate to severe neurotrauma needs further extensive studying. Only one small prospective, randomized, double blind trail of statin treatment initiation within $24 \mathrm{~h}$ of moderate TBI was found. ${ }^{[62]}$ The study included only 8 patients with statin and the 13 controls. The statin administration was associated with a reduced duration of amnesia (hazard ratio 53.76, 95\% CI 1.58-1,824.64), but no difference in disability at 3 months.

\section{STATUS EPILEPTICUS AND EPILEPSY}

Animal models suggest that statin administration might be a therapeutic strategy for epilepsythrough neuroprotection in status epilepticus (SE) and prevention of epileptogenesis progression. ${ }^{[63-66]}$ Lovastatin administration after pilocapine-induced SE suppressed mRNA expression of hippocampal cytokines (such as interleukin-1b, interleukin-6, tumor necrosis factor a, and kinin B1 recepter) and reduced SE-induced hypothermia. ${ }^{[63]}$ Lovastatin also decreased cell loss in hippocampal CA1, CA3 and hilus of dentate gyrus after pilocapine-induced SE that is a critical step of epileptogenesis. ${ }^{[64]}$ In the chronic temporal lobe epilepsy (TLE) model, 2 weeks administration of simvastatin after kainic acid-induced SE lead to not only attenuated microscopic morphological changes, but also reduced seizure activity in the brain at 4 to 6-month after SE. ${ }^{[65]}$ On the other hand, 2 weeks treatment of atorvastatin did not affect the duration of SE or development of epilepsy in electrically induced rat TLE model. ${ }^{[66]}$

There is no evidence that the neuroprotective properties of statin will have a clinical benefit in acute epileptic syndromes.

\section{CENTRAL NERVOUS SYSTEM INFECTION}

Simvastatin can attenuate leukocyte invasion into the central nervous system (CNS) and systemic complication of pneumococcal meningitis in an experimental model of bacterial meningitis rodents. ${ }^{[67]}$ Simvastatin treatment significantly reduced cerebrospinal fluid leukocyte counts with dose-dependent manner, but did not altered cerebellar bacterial titers. The marked hypothermia was dose-dependently reversed by statin treatment. This neuroprotective effects can be explained by anti-inflammatory pleiotropic property of the statin. Statin treatment did not result in an improvement of the clinical score or a reduction of increased intracranial pressure and blood-barrier breakdown. Clinical studies of the effects of statin treatment in acute CNS infection are lacking.

\section{CONCLUSION}

Some preclinical and clinical evidence has shown that statin therapy following SAH could be safe and beneficial in terms of reducing DCI and possibly cerebral vasospasm and early in-hospital mortality. However, methodology of clinical studies was varied and beneficial effects were inconsistent, statin therapy following SAH should not be considered standard care at this time. Statin use before ICH or before and during acute ischemic stroke is safe and can reduce in-hospital mortality and improve functional outcome, whereas statin withdrawal in the hospital after acute ischemic stroke, even for a brief period, can cause early neurologic deterioration and death. Despite the lack of clinical evidence for statin initiation after ICH or acute ischemic stroke, we can achieve better long-term compliance with in-hospital initiation when statin therapy is indication. Even though benefit in preclinical studies, there is no clinical evidence that the pleiotropic properties of statins will have a clinical benefit in neurotrauma, epilepsy and CNS infection.

\section{Financial support and sponsorship}

Nil. 


\section{Conflicts of interest}

There are no conflicts of interest.

\section{REFERENCES}

1. Zhou Q, Liao JK. Pleiotropic effects of statins-Basic research and clinical perspectives. Circ J 2010;74:818-26.

2. Greenwood J, Steinman L, Zamvil SS. Statin therapy and autoimmune disease: from protein prenylation to immunomodulation. Nat Rev Immunol 2006;6:358-70.

3. George SJ, Dhond AJ, Alderson SM, Ezekowitz MD. Neuroprotective effects of statins may not be related to total and low-density lipoprotein cholesterol lowering. Am J Cardiol 2002;90:1237-9.

4. Brouilette SW, Moore JS, McMahon AD, Thompson JR, Ford I, Shepherd J, Packard CJ, Samani NJ. West of Scotland Coronary Prevention Study Group. Telomere length, risk of coronary hear disease, and statin treatment in the west of scotland primary prevention study: a nested case-control study. Lancet 2007;369:107-14

5. Heart Protection Study Collaborative Group. MRC/BHF heart protection study of cholesterol lowering with simvastatin in 20,536 high-risk individuals: a randomised placebo-controlled trial. Lancet 2002;360:7-22

6. Amarenco P, Bogousslavsky J, Callahan A3rd, Goldstein LB, Hennerici M, Rudolph AE, Sillesen H, Simunovic L, Szarek M, Welch KM, Zivin JA. Stroke Prevention by Aggressive Reduction in Cholesterol Levels (SPARCL) Investigators. High-dose atorvastatin after stroke or transient ischemic attack. NEngl J Med 2006;355:549-59.

7. Schwartz GG, Olsson AG, Ezekowitz MD,Ganz P, Oliver MF, Waters D, Zeiher A, Chaitman BR, Leslie S, Stern T. Myocardial Ischemia Reduction with Aggressive Cholesterol Lowering (MIRACL) Study Investigators. Effects of atorvastatin on early recurrent ischemic events in acute coronary syndromes: the MIRACL study: a randomized controlled trial. JAMA 2001:285:1711-8.

8. Martí-Fàbregas J, Gomis M, Arboix A, Aleu A, Pagonabarraga J, Belvís R, Cocho D, Roquer J, Rodríguez A, García MD, Molina-Porcel L, DíazManera J, Martí-Vilalta JL. Favorable outcome of ischemic stroke in patients pretreated with statins. Stroke 2004;35:1117-21.

9. Clatterbuck RE, Oshiro EM, Hoffman PA, Dietsch GN, Pardoll DM, Tamargo RJ. Inhibition of vasospasm with lymphocyte functionassociated antigen-1 monoclonal antibody in a femoral artery model in rats. J Neurosurg 2002;97:676-82.

10. Dumont AS, Dumont RJ, Chow MM, Lin CL, Calisaneller T, Ley KF, Kassell NF, Lee KS. Cerebral vasospasm after subarachnoid hemorrhage: putative role of inflammation. Neurosurgery 2003;53:12333; discussion 133-5.

11. Dhar R, Diringer M. Statins and anti-inflammatory therapies for subarachnoid hemorrhage. Curr Treat Options Neurol 2012;14:164-74.

12. Bulsara KR, Coates JR, Agrawal VK, Eifler DM, Wagner-Mann CC Durham HE, Fine DM, Toft K. Effect of combined simvastatin and cyclosporine compared with simvastatin alone on cerebral vasospasm after subarachnoid hemorrhage in a canine model. Neurosurg Focus 2006;21:E11.

13. McGirt MJ, Lynch JR, Parra A, Sheng H, Pearlstein RD, Laskowitz DT, Pelligrino DA, Warner DS. Simvastatin increases endothelial nitric oxide synthase and ameliorates cerebral vasospasm resulting from subarachnoid hemorrhage. Stroke 2002;33:2950-6.

14. McGirt MJ, Pradilla G, Legnani FG, Thai QA, Recinos PF, Tamargo RJ, Clatterbuck RE. Systemic administration of simvastatin after the onset of experimental subarachnoid hemorrhage attenuates cerebral vasospasm. Neurosurgery 2006;58:945-51; discussion 945-51.

15. Tseng MY, Czosnyka M, Richards H, Pickard JD, Kirkpatrick PJ. Effects of acute treatment with pravastatin on cerebral vasospasm, autoregulation, and delayed ischemic deficits after aneurysmal subarachnoid hemorrhage: a phase II randomized placebo-controlled trial. Stroke 2005;36:1627-32.

16. Lynch JR, Wang H, McGirt MJ, Floyd J, Friedman AH, Coon AL, Blessing R, Alexander MJ, Graffagnino C, Warner DS, Laskowitz DT. Simvastatin reduces vasospasm after aneurysmal subarachnoid hemorrhage: Results of a pilot randomized clinical trial. Stroke 2005;36:2024-6

17. Chou SH, Smith EE, Badjatia N, Nogueira RG, Sims JR 2nd, Ogilvy CS, Rordorf GA, Ayata C. A randomized, double-blind, placebocontrolled pilot study of simvastatin in aneurysmal subarachnoid hemorrhage. Stroke 2008;39:2891-3.
18. Vergouwen MD, Meijers JC, Geskus RB, Coert BA, Horn J, Stroes ES, van der Poll T, Vermeulen M, Roos YB. Biologic effects of simvastatin in patients with aneurysmal subarachnoid hemorrhage: A doubleblind, placebo-controlled randomized trial. J Cereb Blood Flow Metab 2009;29:1444-53.

19. Jaschinski U, Scherer K, Lichtwarck M, Forst H. Impact of treatment with pravastatin on delayed ischemic disease and mortality after aneurysmal subarachnoid hemorrhage. Crit Care 2008;12:P112.

20. Macedo S, Bello Y, Silva A, Siqueria C, Siqueria S, Brito L. Effects of simvastatin in prevention of vasospasm in nontraumatic subarachnoid hemorrhage: preliminary data. Crit Care 2009;13:P103.

21. Kramer AH, Gurka MJ, Nathan B, Dumont AS, Kassell NF, Bleck TP. Statin use was not associated with less vasospasm or improved outcome after subarachnoid hemorrhage. Neurosurgery 2008;62:4227; discussion 427-30.

22. McGirt MJ, Garces Ambrossi GL, Huang J, Tamargo RJ. Simvastatin for the prevention of symptomatic cerebral vasospasm following aneurysmal subarachnoid hemorrhage: a single-institution prospective cohort study. J Neurosurg 2009;110:968-74.

23. Kern M, Lam MM, Knuckey NW, Lind CR. Statins may not protect against vasospasm in subarachnoid haemorrhage. $J$ Clin Neurosci 2009;16:527-30.

24. Kerz T, Victor A, Beyer C, Trapp I, Heid F, Reisch R. A case control study of statin and magnesium administration in patients after aneurysmal subarachnoid hemorrhage: Incidence of delayed cerebral ischemia and mortality. Neurol Res 2008;30:893-7.

25. Singhal AB, Topcuoglu MA, Dorer DJ, Ogilvy CS, Carter BS Koroshetz WJ. SSRland statin use increases the risk for vasospasm after subarachnoid hemorrhage. Neurology 2005;64:1008-13.

26. Sanchez-Pena P, Nouet A, Clarencon F, Colonne C, Jean B, Le Jean L, Fonfrede M, Aout M, Vicaut E, Puybasset L.Atorvastatin decreases computed tomography and S100-assessed brain ischemia after subarachnoid aneurysmal hemorrhage: a comparative study. Crit Care Med 2012:40:594-602

27. Kramer AH, Fletcher JJ. Statins in the management of patients with aneurysmal subarachnoid hemorrhage: a systematic review and metaanalysis. Neurocrit Care 2010;12:285-96.

28. Biffi A, Devan WJ, Anderson CD, Ayres AM, Schwab K, Cortellini L Viswanathan A, Rost NS, Smith EE, Goldstein JN, Greenberg SM Rosand J. Statin use and outcome after intracerebral hemorrhage: case-control study and meta-analysis. Neurology 2011;76:1581-8.

29. Jung KH, Chu K, Jeong SW, Han SY, Lee ST, Kim JY, Kim M, Roh JK. HMG-CoA reductase inhibitor, atorvastatin, promotes sensorimotor recovery, suppressing acute inflammatory reaction after experimental intracerebral hemorrhage. Stroke 2004;35:1744-9.

30. Seyfried D, Han Y, LuD, Chen J, Bydon A, Chopp M. Improvement in neurological outcome after administration of atorvastatin following experimental intracerebral hemorrhage in rats. $J$ Neurosurg 2004;101:104-7.

31. Indraswari F, Wang H, Lei B, James ML, Kernagis D, Warner DS, Dawson HN, Laskowitz DT. Statins improve outcome in murine models of intracranial hemorrhage and traumatic brain injury: a translational approach. J Neurotrauma 2012;29:1388-400.

32. Chen J, Zhang ZG, Li Y, Wang Y, Wang L, Jiang H, Zhang C, Lu M Katakowski M, Feldkamp CS, Chopp M. Statins induce angiogenesis, neurogenesis, and synaptogenesis after stroke. Ann Neurol 2003;53:743-51.

33. Leker RR, Khoury ST, Rafaeli G, Shwartz R, Eichel R, Tanne D, NASIS Investigators. Prior use of statins improves outcome in patients with intracerebral hemorrhage: Prospective data from the National Acute Stroke Israeli Surveys (NASIS). Stroke 2009;40:2581-4.

34. Goldstein LB, Amarenco P, Szarek M, Callahan A 3rd, Hennerici M, Sillesen H, Zivin JA, Welch KM; SPARCL Investigators. Hemorrhagic stroke in the stroke prevention by Aggressive Reduction in Cholesterol Levels study. Neurology 2008;70:2364-70.

35. Hackam DG, Woodward M, Newby LK, Bhatt DL, Shao M, Smith EE, Donner A, Mamdani M, Douketis JD, Arima H, Chalmers J, MacMahon S, Tirschwell DL,Psaty BM, Bushnell CD, Aguilar MI, Capampangan DJ, Werring DJ, De Rango P, Viswanathan A, Danchin N, Cheng CL, Yang YH, Verdel BM, Lai MS, Kennedy J, Uchiyama S, Yamaguchi T, Ikeda Y, Mrkobrada M. Statins and intracerebral hemorrhage: collaborative systematic review and meta-analysis. Circulation 2011;124:2233-42.

36. Cholesterol Treatment Trialists' C, Blackwell L, Emberson J, Holland LE, Reith C, Bhala N, Peto R, Barnes EH, Keech A, Simes J, Collins $\mathrm{R}$. Efficacy and safety of more intensive lowering of LDL cholesterol: 
a meta-analysis of data from 170,000 participants in 26 randomised trials. Lancet 2010;376:1670-81.

37. García-Bonilla L, Campos M, Giralt D, Salat D, Chacón P, HernándezGuillamon M, Rosell A, Montaner J. Evidence for the efficacy of statins in animal stroke models: A meta-analysis. J Neurochem 2012;122:233-43.

38. Endres M, Laufs U, Huang Z, Nakamura T, Huang P, Moskowitz MA, Liao JK.Stroke protection by 3-hydroxy-3-methylglutaryl (HMG)-CoA reductase inhibitors mediated by endothelial nitric oxide synthase. Proc Natl Acad Sci U S A 1998;95:8880-5.

39. Yamada M, Huang Z, Dalkara T, Endres M, Laufs U, Waeber C, Huang PL, Liao JK, Moskowitz MA. Endothelial nitric oxide synthasedependent cerebral blood flow augmentation by L-arginine after chronic statin treatment. J Cereb Blood Flow Metab 2000;20:709-17.

40. Cui W, Matsuno K, Iwata K, Ibi M, Katsuyama M, Kakehi T, Sasaki M, Ikami K, Zhu K, Yabe-Nishimura C. NADPH oxidase isoforms and anti-hypertensive effects of atorvastatin demonstrated in two animal models. J Pharmacol Sci 2009;111:260-8.

41. Hong H, Zeng JS, Kreulen DL, Kaufman DI, Chen AF. Atorvastatin protects against cerebral infarction via inhibition of NADPH oxidasederived superoxide in ischemic stroke. Am J Physiol Heart Circ Physiol 2006;291:H2210-5.

42. Aboa-Eboulé C, Binquet C, Jacquin A, Hervieu M, Bonithon-Kopp C, Durier J, Giroud M, Béjot Y. Effect of previous statin therapy on severity and outcome in ischemic stroke patients: a population-based study. J Neurol 2013;260:30-7.

43. Elkind MS, Flint AC, Sciacca RR, Sacco RL. Lipid-lowering agent use at ischemic stroke onset is associated with decreased mortality. Neurology 2005;65:253-8.

44. Greisenegger S, Müllner M, Tentschert S, Lang W, Lalouschek W. Effect of pretreatment with statins on the severity of acute ischemic cerebrovascular events. J Neurol Sci 2004;221:5-10.

45. Flint AC, Kamel H, Navi BB, Rao VA, Faigeles BS, Conell C, Klingman JG, Sidney S, Hills NK, Sorel M, Cullen SP, Johnston SC.Statin use during ischemic stroke hospitalization is strongly associated with improved poststroke survival. Stroke 2012;43:147-54

46. Blanco M, Nombela F, Castellanos M, Rodriguez-Yáñez M, García-Gil M, Leira R, Lizasoain I, Serena J, Vivancos J, Moro MA, Dávalos A, Castillo J.Statin treatment withdrawal in ischemic stroke: a controlled randomized study. Neurology 2007;69:904-10.

47. Kennedy J, Hill MD, Ryckborst KJ, Eliasziw M, Demchuk AM, Buchan AM, FASTER Investigators. Fast assessment of stroke and transient ischaemic attack to prevent early recurrence (FASTER): a randomised controlled pilot trial. Lancet Neurol 2007;6:961-9.

48. Squizzato A, Romualdi E, Dentali F, Ageno W. Statins for acute ischemic stroke. Cochrane Database Sust Rev 2011;10:CD007551.

49. Montaner J, Chacón P, Krupinski J, Rubio F, Millán M, Molina CA, Hereu P, Quintana M, Alvarez-Sabín J.Simvastatin in the acute phase of ischemic stroke: a safety and efficacy pilot trial. Eur J Neurol 2008;15:82-90.

50. Cao H, Sun CK, Zhao J, Zhao GY, Tang SL, Wang QY, Hou Y, Xu J, Tao DB, Liu XS, Huang AL. Effect of statins on neurological impairment and correlative parameters in serum in patients with cerebral infarction. Chinese Journal of Clinical Rehabilitation 2005;9:94-6.

51. Elkind MS, Sacco RL, Macarthur RB, Peerschke E, Neils G, Andrews $\mathrm{H}$, Stillman J, Corporan T, Leifer D, Liu R, Cheung K. High-dose lovastatin for acute ischemic stroke: results of the phase I dose escalation neuroprotection with statin therapy for acute recovery trial (NeuSTART). Cerebrovasc Dis 2009;28:266-75.

52. Amarenco P BJ, Callahan A 3rd, Goldstein LB, Goldstein LB, Hennerici M, Rudolph AE, Sillesen H, Simunovic L, Szarek M, Welch KM, Zivin JA; Stroke Prevention by Aggressive Reduction in Cholesterol
Levels (SPARCL) Investigators. High-dose atorvastatin after stroke or transient ischemic attack. NEngl J Med 2006;355:549-59.

53. Lappe JM, Muhlestein JB, Lappe DL, Badger RS, Bair TL, Brockman R, French TK, Hofmann LC, Horne BD, Kralick-Goldberg S, Nicponski N, Orton JA,Pearson RR, Renlund DG, Rimmasch H, Roberts C, Anderson JL. Improvements in 1-year cardiovascular clinical outcomes associated with a hospital-based discharge medication program. Ann Intern Med 2004;141:446-53.

54. Ovbiagele B, Saver JL, Fredieu A, Suzuki S, McNair N, Dandekar A, Razinia T, Kidwell CS. PROTECT: a coordinated stroke treatment program to prevent recurrent thromboembolic events. Neurology 2004;63:1217-22

55. Sanossian N, Saver JL, Liebeskind DS, Kim D, Razinia T, Ovbiagele B. Achieving target cholesterol goals after stroke: is in-hospital statin initiation the key? Arch Neurol 2006;63:1081-3.

56. Chen S-F, Hung T-H, Chen C-C, Lin KH, Huang YN, Tsai HC, Wang JY. Lovastatin improves histological and functional outcomes and reduces inflammation after experimental traumatic brain injury. Life Sci 2007;81:288-98.

57. Chen G, ZhangS, Shi J, AiJ, QiM, Hang C. Simvastatin reduces secondary brain injury caused by cortical contusion in rats: possible involvement of TLR4/NF-kappa B pathway. Exp Neurol 2009;216:398-406.

58. Turkoglu OF, Eroglu H, Okutan O, Gurcan O, Bodur E, Sargon MF, Oner L, Beskonakl i E. Atorvastatin efficiency after traumatic brain injury in rats. Surg Neurol 2009;72:146-52.

59. Lu D, Qu C, Goussev A, Jiang H, Lu C, Schallert T, Mahmood A, Chen J, Li Y, Chopp M.Statins increase neurogenesis in the dentate gyrus, reduce delayed neuronal death in the hippocampal CA3 region, and improve spatial learning in rat after traumatic brain injury. $\mathcal{J}$ Neurotrauma 2007:24:1132-46.

60. Han X, Yang N, Xu Y, Zhu J, Chen Z, Liu Z, Dang G, Song C. Simvastatin treatment improves functional recovery after experimental spinal cord injury by upregulating the expression of BDNF and GDNF. Neurosci Lett 2011;487:255-9.

61. Déry MA, Rousseau G, Benderdour M, Beaumont E. Atorvastatin prevents early apoptosis after thoracic spinal cord contusion injury and promotes locomotion recovery. Neurosci Lett 2009;453:73-6.

62. Tapia-Perez J, Sanchez-Aguilar M, Torres-Corzo JG, Gordillo-Moscoso A, Martinez-Perez P, Madeville P, de la Cruz-Mendoza E, Chalita-Williams J. Effect of rosuvastatin on amnesia and disorientation after traumatic brain injury (NCT003229758). J Neurotrauma 2008:25:1011-7.

63. Gouveia TL, Scorza FA, Silva MJ, Bandeira Tde A, Perosa SR, Argañaraz GA, Silva Mde P, Araujo TR, Frangiotti MI, Amado D, Cavalheiro EA, Silva JA Jr, Naffah-Mazzacoratti Mda G. Lovastatin decreases the synthesis of inflammatory mediators in the hippocampus and blocks the hyperthermia of rats submitted to long-lasting status epilepticus. Epilepsy Behav 2011:20:1-5.

64. Rangel P, Cysneiros RM, Arida RM, de Albuquerque M, Colugnati DB, Scorza CA, Cavalheiro EA, Scorza FA. Lovastatin reduces neuronal cell death in hippocampal CA1 subfield after pilocarpine-induced status epilepticus: Preliminary results. Arq Neuropsiquiatr 2005;63:972-6.

65. Xie C, Sun J, Qiao W, Lu D, Wei L, Na M, Song Y, Hou X, Lin Z. Administration of simvastatin after kainic acid-induced status epilepticus restrains chronic temporal lobe epilepsy. PLoS One 2011;6:e24966.

66. van Vliet EA, Holtman L, Aronica E, Schmitz LJ, Wadman WJ, Gorter JA. Atorvastatin treatment during epileptogenesis in a rat model for temporal lobe epilepsy. Epilepsia 2011;52:1319-30.

67. Winkler F, Angele B, Pfister HW, Koedel U. Simvastatin attenuates leukocyte recruitment in experimental bacterial meningitis. Int Immunopharmacol 2009;9:371-4. 